九州大学学術情報リポジトリ

Kyushu University Institutional Repository

Futanari, Between and Beyond : From Male Shamans to Hermaphrodites in The Illustrated Scroll of Illnesses

Yamamoto, Satomi

Kyoritsu Women's University : Professor of Japanese Art History

https://doi.org/10.5109/1917885

出版情報: Journal of Asian Humanities at Kyushu University. 3, pp.77-85, 2018-03. Kyushu University, School of Letters, Graduate School of Humanities, Faculty of Humanities バージョン:

権利関係 : 


\title{
Futanari, Between and Beyond: From Male Shamans to Hermaphrodites in The Illustrated Scroll of IIInesses
}

\author{
SATOMI YAMAMOTO
}

\section{Introduction}

$\boldsymbol{Y}$ AMAI no sōshi 病草紙 (The Illustrated Scroll of Illnesses) is thought to have been completed in the late twelfth century, around the zenith of Emperor Goshirakawa’s 後白河上皇 (1127-1192) cultural influence. It contains twenty-one depictions in its extant form. Not limited to basic ailments such as toothaches and abdominal pain, the scroll also includes depictions of a great variety of medical cases such as hermaphroditism, albinism, and dwarfism.

Among these cases is an entry titled "Futanari" 二 形, which depicts an intersex soothsayer, a figure seemingly based on Heian-period (794-1185) male shamans (otoko miko or okannangi 男巫) who sometimes dressed in women's clothing. This essay investigates the culture of male shamans with respect to their depiction

The author would like to thank Eric Jose Estaban for his translation of the first draft of this essay. This essay is based on the author's presentation for the 2017 AAS Annual Conference in Toronto, March 2017, as part of the following panel: "Deforming, Transforming, and Performing: Twelfth-Century Space Travel through Liminal Bodies." Organizer: Takeshi Watanabe, Assistant Professor, Wesleyan University; Discussant: Estelle LeggeriBauer, Professor, INALCO.

1 For all twenty-one depictions, see Kasuya and Yamamoto, Yamai no sōshi, pp. 2-43. in The Illustrated Scroll of Illnesses. ${ }^{2}$

As in the case of Himiko 卑弥呼 of Yamataikoku 邪 馬台国 in ancient Japan, shamans who mediated the gods' oracles were mainly women, although some were men. For example, the Midō kanpaku-ki 御堂関白記 (Diary of the Midō Regent) by Fujiwara no Michinaga 藤原道長 (966-1029) contains an account in which a male shaman was summoned to treat Emperor Sanjō's 三条天皇 (976-1017) eye disease on the thirteenth day of the sixth month of Chōwa 長和 4 (1015). Based on this document, it seems Michinaga and his contemporaries could choose between female and male shamans. At the time there was no sense that a male shaman was a strange phenomenon.

A different perspective on male shamans can be found in the popular songs, or imayo 今樣, of the late Heian period. These songs were recorded in the Ryojin hishō 梁塵秘抄 (Songs to Make the Dust Dance on the Beams), compiled around the Jishō 治承 era (11771181) by Retired Emperor Goshirakawa. Some of the songs make reference to male shamans, mocking them

\footnotetext{
2 In this essay, the word "soothsayer" indicates the futanari's profession. It is based on the following text found in the scroll: "A man who walked around... and told fortunes" (占し歩く男). On the other hand, the word "male shaman" corresponds to the translation of the historical term otoko miko or okannangi.
} 


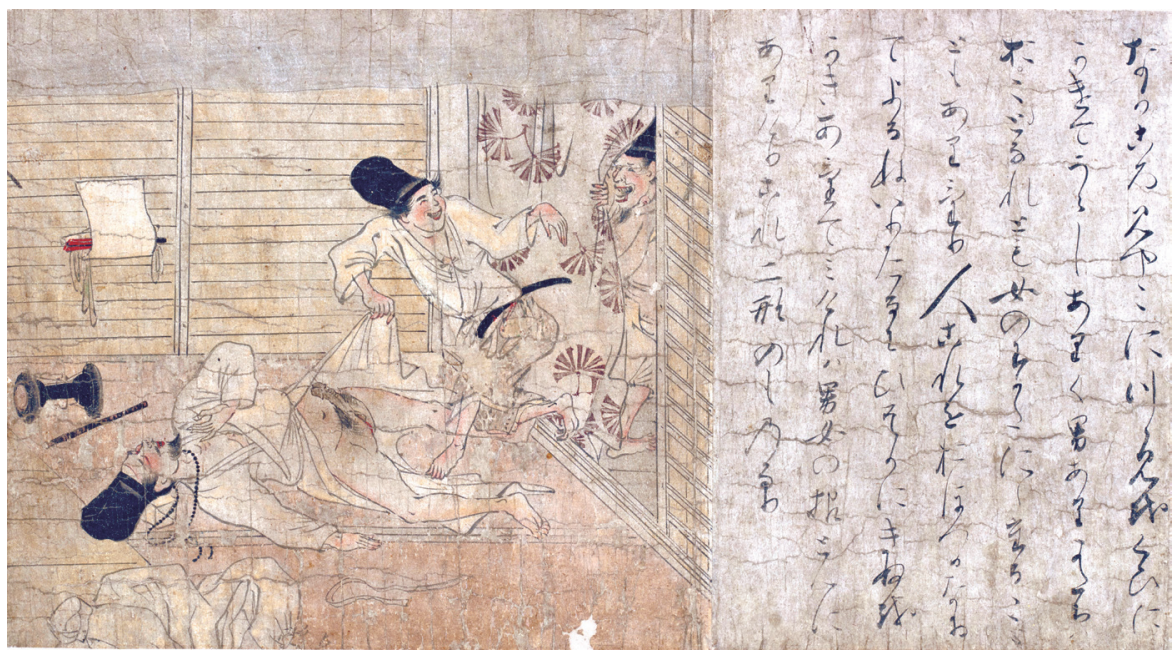

Figure 1. "Futanari," a section of Yamai no sōshi. 12th c., Heian period. $\mathrm{H} 26.2 \mathrm{~cm}, W 47.6 \mathrm{~cm}$. Handscroll, ink and colors on paper. Collection Kyoto National Museum, reproduced with permission.

for their ties to the marginal cultures of the eastern hinterlands and the emerging warrior class. Furthermore, these songs show the same kind of mocking gaze cast upon the intersex soothsayer in the text and image of "Futanari." In this essay I will discuss the basis of the multiple meanings of "Futanari" and the term futanari by focusing on Buddhist teachings and the Heian-period culture of male shamans. ${ }^{3}$

\section{Description and Illustration in "Futanari"}

The "Futanari" section, currently held at the Kyoto National Museum, features an intersex soothsayer. $\mathrm{He}$ is described as follows:

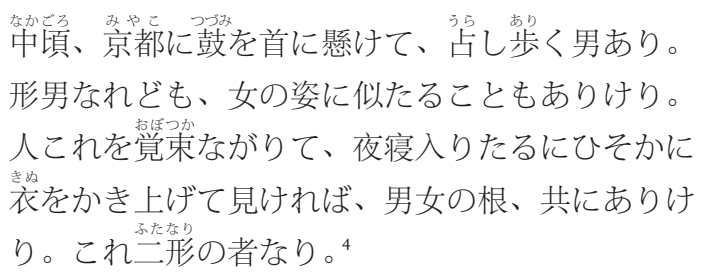

Not too long ago, there was a man who walked around the capital. He had a drum hanging from his neck and told fortunes. He looked like a man, but it is said that, in certain aspects, he resembled a woman. Thinking that was strange, some people crept in on him while he was asleep at night. Lifting up his clothing, they looked and saw that he had the organs of both a man and a woman. He was someone of "two forms."

The illustration depicts a man sneaking into the soothsayer's bedchamber (figure 1). Lifting the soothsayer's gown, the man discovers that the soothsayer has both male and female sex organs.

At first glance, the intersex figure, wearing a black eboshi 烏帽子 hat and a fully grown beard, appears to be depicted as a male figure. Upon closer inspection, however, the more feminine characteristics of the person-his red-painted lips and cheeks, as well as the red fan hanging on the wall - tell a different story. Moreover, the prayer beads hanging from his neck as well as the flute and drum by his pillow all suggest that he works as a shaman. The intruder invites another man to come closer. Although the second man is clearly attempting to escape the scene, with the lower half of his body turned away from the room, his face peeping from behind the curtains betrays his curiosity. The two intruders laugh and sneer as they look upon the sleeping person's genitalia.

\footnotetext{
3 Also see Yamamoto, "'Yamai no sōshi' ni okeru setsuwa no ryōbun."

4 Kasuya and Yamamoto, Yamai no sōshi, p. 240
} 


\section{Medical Science and Sutra Teachings Regarding Hermaphroditism}

According to present-day medical science, "intersex" is understood to be a condition in which a deviation from the typical development of the sexual organs has occurred. There are several causes - for example, variations in chromosomes and gonads, or a hormonal imbalance.

A case such as that illustrated in this work of both the male and the female external genitalia developing into adulthood cannot, however, be verified medically. In other words, the illustration does not depict a medical condition that is known to exist naturally. Rather, it depicts a fictitious patient associated with the word futanari. What are the word's origins and how was it used in the Heian period?

This condition is not identified in the Ishinpō 医心 方 (Formulas From the Heart of Medicine), a medical treatise in thirty volumes completed by the mid-Heianperiod physician Tanba no Yasunori 丹波康則 (912995), who referenced handwritten Chinese medical documents dating to no later than the eighth century. On the other hand, the words futanari and the synonymous nikon二根 appear frequently in Buddhist sutras.

Bussetsu daijō zōzō kudokukyō 仏説大乗造像功徳 経 (Sutra of Mahayana Buddhism on the Merit of the Construction of the Buddha's Image), which describes the construction of a statue of Sākyamuni (the historical buddha) by King Udayana, is but one example of the word's frequent appearance in Buddhist texts. The sutra opens with the virtuous construction of a Buddhist statue and explains that people are always born as men, and not as women, eunuchs, hermaphrodites, or others of low rank. The sutra divides the human race into four varieties: men, women, eunuchs, and hermaphrodites, and states that not being born a man is a form of karmic retribution because, according to Buddhist thought, only men have the potential to be a Buddha.

Similar teachings are included in the Shōbo nenjokyō 正法念処経 (Sutra of Meditation on the True Law), which is also one of the sources for Jigoku zōshi 地獄草 紙 (The Scroll of Hell) and Gaki zōshi 餓鬼草紙 (The Scroll of Hungry Ghosts). ${ }^{6}$ Within the "Meditation on

5 Bussetsu daijō zōzō kudokukyō, p. 793c.

6 These scrolls are thought to have been produced as a series of rokudō-e 六道絵 along with The Illustrated Scroll of IIInesses. See Ueno, "Emakimono ni tsuite"; Tanaka, Jigoku zōshi; the Body” chapter (Shinnenjobon 身念処品), a passage regarding “The Womb-Turning Wind” 転胎蔵風 dictates how the different sexes are divided:

For acts of evil committed in a previous life, one who was intended to be a man instead becomes a woman. Another becomes a eunuch, while another dies in the womb. Given that this is caused by sins, those without sin from a previous life do not suffer punishment. $^{7}$

This passage, which uses words such as "a man instead becomes a woman," is reminiscent of the description in "Futanari" ("Although his appearance was that of a man, he would occasionally dress as a woman") as well as the visual depiction of the person having both male and female sex organs.

This sutra also attributes eunuchry to licentious acts committed in a previous life. For example, in the "Beasts" chapter (Chikushōbon 畜生品), ${ }^{8}$ those who engage in bestiality or force others to commit crimes first descend into hell, then become beasts, and when they finally achieve rebirth in the human realm they do so in the form of a eunuch. ${ }^{9}$

In the "Ten Good or Bad Deeds" chapter (Jüzengōdōbon 十善業道品), the word nikon, synonymous with the word futanari, appears in a passage that explains, "Those who enjoy acts of licentiousness will enter the realm of hell, hungry ghosts, or beasts. Even if they are reborn as humans, their wives will not be obedient, or they will be hermaphrodites scorned by the world."10

The intersex figure in The Illustrated Scroll of Illnesses faces ridicule from society as represented by the two intruders in the illustration and the unspecified number of people mentioned in the text. This disdain and derision reflects teachings about karmic retribution found in the Buddhist sutras. Since Shōbo nenjokyō is one of the sources of the Scroll of Hell and the Scroll of Hungry Ghosts, this sutra would have been familiar to the creators of the picture scrolls in the Heian period. For both the creators and readers of this scroll, a hermaphrodite

Kobayashi, "Hekija emaki ni tsuite" and "Butsumyō to Shamon jigoku"; Shinbo, "Harake-bon Jigoku zōshi no gadai to shutten"; Umezawa, "Ya o hagu Bishamonten zō to 'hekija-e' no shudai."

7 Shōbō nenjokyō, p. 392b.

8 Although the chapter is called "Beasts," it also includes the realm of Ashura 阿修羅.

9 Shōbō nenjokyō, p. 104a-b

10 Ibid., p. 3c. 
would have been recognized as an object of derision and an obviously sinful individual. It is at this juncture that The Illustrated Scroll of Illnesses and teachings from sutras coincide.

However, the depiction in The Illustrated Scroll of Illnesses has many issues that cannot be explained by Buddhist sutras. The "Futanari" scene also contains many items that came from outside the sutras. The text describes the figure as a wandering "soothsayer," and even the illustration depicts prayer beads around the man's neck as well as the characteristic possessions of a shaman, a flute and drum, strewn on the floor.

Why are these attributes associated with a futanari? The answer can be found only in the contemporaneous existence during the Heian period of these androgynous soothsayers - male shamans in women's clothing. The work's depiction of the futanari thus reflects the superimposition of the sutra's conception of intersexuality onto a male shaman. ${ }^{11}$ In this way, the text and image of "Futanari" can be connected to the actual state of male shamans in the Heian period.

\section{The Male Shaman in the Mido kanpaku-ki}

The Heian period saw the existence of male shamans in women's clothing who acted as mediums. As already mentioned, Fujiwara no Michinaga's Midō kanpaku-ki contains an account in which a male shaman is summoned on the thirteenth day of the sixth month of Chōwa 4 (1015) to treat Emperor Sanjō's eye disease:

\begin{abstract}
Thirteenth day of the year of kanoto-u [辛卯, 1015]. Lord Sukehira said, "There is someone who claims he can cure His Majesty's eyes. What do you think about having him do it?" Then Lord Sukehira explained the method of the cure: "We will have the person make offerings and perform the ritual near Kitano." I agreed with his suggestion. Soon after, I went to the palace to confirm the details of this. It was a male shaman, and he was rewarded with a few gifts. $^{12}$
\end{abstract}

This is a record from the period when various prayers

11 Abe, "Sei no rinkai o ikiru"; Abe, "Sei no ekkyō," pp. 206-12.

12 Yamanaka, Midō kanpaku-ki zenchūshaku: Chōwa 4 nen, pp. 112-13. were offered for Emperor Sanjō, who had been suffering from an eye disease for some time. News of the male shaman coming to cure Emperor Sanjō's eye disease was relayed to Michinaga through Fujiwara no Sukehira 藤原資平 (986-1068), who acted as an intermediary between Emperor Sanjō and Michinaga during their frequent political disagreements.

Michinaga ordered that rites be performed-rites in which someone would "make offerings and perform a ritual near Kitano." Then he went to the palace immediately to confirm the details of the shaman. Finally he was informed it was a male shaman.

"Near Kitano" refers to a location in the vicinity of Kitano Tenmangū Shrine 北野天満宮. It remains unclear whether the male shamans who performed rituals at the time did so in women's clothing. The fact that Michinaga uses the term "male shaman," however, suggests that the word "shaman" was inherently associated with women. Multiple studies have found that it was largely women who acted as oracles, mediums, and soothsayers. ${ }^{13}$

We can look to Yanagita Kunio's early work of 1913 to 1914, "Fujo kō" 巫女考 (On Shrine Maidens), which consists of groundbreaking research on the traditions of female shamans and soothsayers all around Japan. ${ }^{14}$ He would later continue this work in "Tamayorihime kō” 玉依姫考 (On Tamayorihime, 1917), in which he focused on the role women played with regard to the gods of heaven and earth. ${ }^{15}$ Yanagita developed his ideas further in “Tamayorihiko no mondai” 玉依彦の問題 (The Problem of Tamayorihiko, 1937), which explored the tradition of a pair of brother and sister gods (onarigami おなり神) in Okinawa. ${ }^{16} \mathrm{~A}$ few years later he published one of his landmark works, Imo no chikara 妹の 力 (Sisters' Power, 1940), which examined female shamans from the viewpoint of native Japanese folklore. ${ }^{17}$ In this study Yanagita argues that women, who in ancient Japan were often the sisters of political statesmen, were in charge of religious rituals. He suggests that in most cases it was women who, as shamans, were tasked

13 Nakayama, Nihon fujo shi; Hori, Nihon no shāmanizumu Yamakami, Miko no rekishi: Nihon shūkyō no botai; Blacker, The Catalpa Bow: A Study of Shamanistic Practices in Japan.

14 The work was serialized in twelve issues of Kyōdo kenkyū 郷土研 究 from March 1913 to February 1914.

15 Yanagita, "Tamayorihime kō."

16 Yanagita, "Tamayorihiko no mondai."

17 Yanagita, Imo no chikara. 
with divining messages from gods and ancestors. Yanagita defines their role as women who provided counsel for the government with the impressive term "the sisters' power." It was this "sisters' power" granted only to women that male shamans attempted to wield.

As additional evidence to prove that the shaman was a women's role, there is an entry on fugeki 巫俔, or shaman, in the Wamyō ruijushō 和名類聚抄, the Japanese dictionary of Chinese characters written by Minamoto no Shitagō 源順 (911-983) in 934. Taken from the Setsumon kaiji 説文解字 (Ch. Shuowen jiezi) of the Eastern Han dynasty (25-220) and the Moji jūryaku文字集略 (Ch. Wenzi jilüe) of the Liang dynasty (502-587), the entry states that, "According to the Setsumon kaiji, the $f u$ 巫, also kamunaki, in fugeki refers to female mediums." ${ }^{18}$ The Moji jüryaku states that the geki 現, also onokokamunaki, refers to male mediums. ${ }^{19}$ Focusing on the Japanese nomenclature of kamunaki (or miko, "medium" or "shrine maiden") and onokokamunaki (or kannagi, "medium" or "diviner"), we can assume that most shamans were female "shrine maidens" and that "male shamans" existed as a separate category.

Going back to the context of the aforementioned Mido kanpaku-ki, could it be possible that Michinaga felt a tinge of surprise or alarm knowing that the person conducting the rituals was a male shaman? Certainly, it is not possible to interpret this as Michinaga's discriminatory feelings toward male shamans. While they did have a role and place different from those of female shrine maidens, it can be assumed based on the account in Midō kanpaku-ki that at times such rituals were conducted by male shamans.

\section{The Dissimilation of Male Shamans}

The views held toward male shamans during the Insei period (1086-1156) must be clarified. The Ryōjin hishō, compiled by Retired Emperor Goshirakawa, is an instructive source for this purpose. ${ }^{20}$ While many of the popular songs, or imayō, were composed by female shamans, a number were composed by male shamans. In the best-known song, male shamans are marginalized as a strange feature of the culture of the eastern provinces (Tōgoku 東国 or Kantō 関東, terms that include a nuance of being far from the capital): "In the east, there are no women, for the gods possess male shamans."

Another song specifically references male shamans: "Oh, how I remember the great mansion of fine horses, the mansion of warriors. Little apprentices dance on the shoulders of magicians, and the diviners were male shamans of Hakata." ${ }^{2}$ In this song, "male shamans of Hakata" could be seen among the gathering of performers at the warriors' mansion with fine horses. Already marginal due to hailing from Kyushu, far from the capital, these male shamans were doubly marginalized within the warrior culture, which itself was marginal in relation to the court nobles in the capital.

Let us look at another song: "At the gate to Sumiyoshi, the dancing shaman is possessed by the gods [tsukigami] and wears borrowed kariginu robes ripped from behind." ${ }^{23}$ Here two words function with double meanings: tsukigami, meaning both "possessed by the gods" (憑神) and “attached hair" (付髪); and kariginu, referring to "hunting robes" (狩衣) worn by men and “clothing borrowed" (借衣) from a female shaman. This song has various interpretations, but two possible images within it are pertinent here: that of a low-ranking shrine maiden dancing near the gate to Sumiyoshi, and that of a dancing male shaman who wears a wig and is dressed in the "borrowed clothes" of a woman. Situated at the farthest point from the main shrine, the image in this song of a shaman who dances at the boundaries of the sacred and the profane can surely mean that he or she is relegated to the fringes of society.

The appearance of male shamans dressed in women's clothing is also described in the Nenchügyōji emaki 年中行事絵巻 (The Illustrated Scroll of Annual Events and Ceremonies), which was completed during Emperor Goshirakawa's lifetime. The sixteen-scroll Sumiyoshi version is considered to be the most faithful copy of the twelfth-century original, which was destroyed in a fire at the beginning of the Edo period (1615-1868). Its third scroll depicts commoners engaging in cockfighting on the grounds of the local shrine. Situated behind them is a humble building where a soothsayer, dressed in exquisite robes, may be seen performing divinations while playing a drum (figure 2). We can assume that this is a male shaman from the moustache on the fig-

\footnotetext{
21 Ryōjin hishō, p. 147 (song 556)

22 Ibid., p. 100 (song 352).

23 lbid., p. 145 (song 545).
}

18 Minamoto no Shitagō, Wamyō ruijushō, p. 568.

19 Nakayama, Nihon fujo shi, p. 6.

20 Kim, Songs to Make the Dust Dance. 


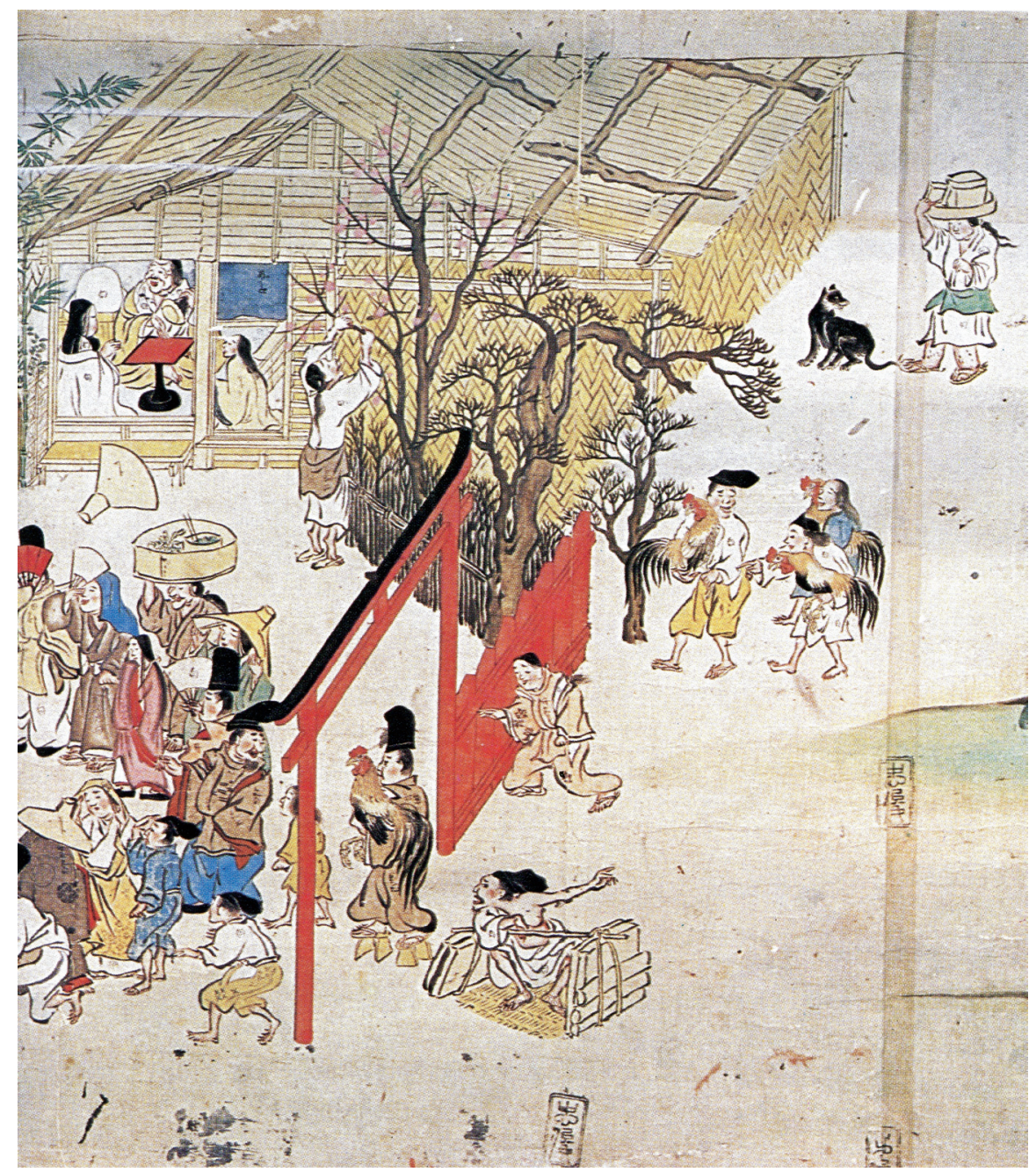

Figure 2. Nenchūgyōji emaki, Sumiyoshi version, scroll III, section 1. 17th c., Edo period. Handscroll, ink and colors on paper. H $45.3 \mathrm{~cm}, \mathrm{~W} 693.9 \mathrm{~cm}$. From Komatsu, Nenchūgyōji emaki, p. 16. Private collection.

ure's face. ${ }^{24}$

The male shaman depicted in this illustration is situated not in the middle of the shrine grounds, but rather in the margins away from the main buildings, performing rituals. This setting calls to mind the previous image of the male shaman in the Mido kanpaku-ki, who was performing rituals at a place vaguely described as "near Kitano." The scene also resonates with the gender-ambiguous shaman at the gate of Sumiyoshi Shrine 住吉神社 in the aforementioned imayō. These male shamans were not affiliated with a particular shrine like priests or shrine maidens, but rather were called "wan- dering shamans," or aruki miko 歩き巫女, low-ranked individuals who moved from place to place acting as spirit mediums and performing divinations.

Let us return to the Ryōjin hishō songs concerning "wandering shamans." One song goes:

My child is surely no longer a child; they say she wanders as a shaman. Surely the fishermen gather 'round her when she walks along the bay of Tago. How they mock her, questioning whether she is right or wrong. How painful her life must be! $!^{25}$
24 Mitsuhashi, Joshō to Nihonjin, pp. 45-52; Komatsu, Nenchūgyōji emaki. 


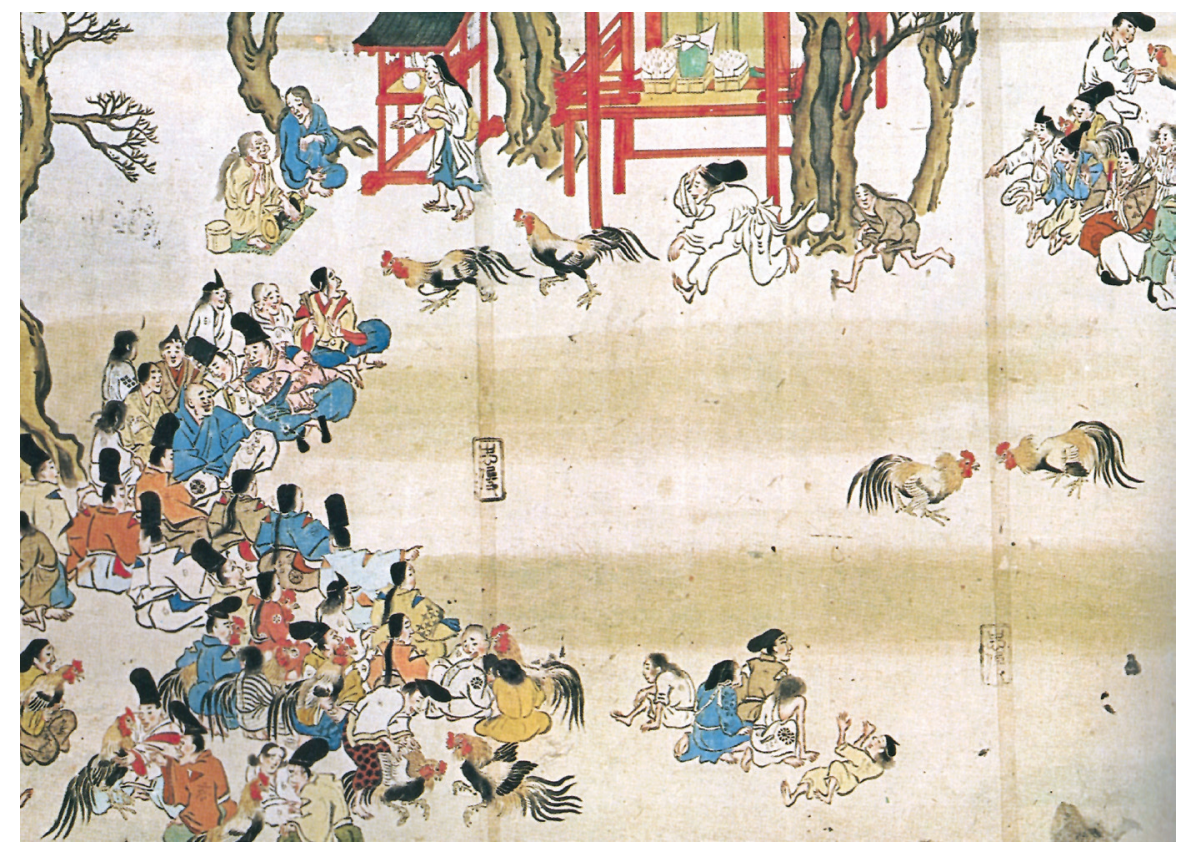

Figure 3. Nenchūgyōji emaki, Sumiyoshi version, scroll III, section 1. 17th c., Edo period. Handscroll, ink and colors on paper. $\mathrm{H} 45.3 \mathrm{~cm}, \mathrm{~W} 693.9 \mathrm{~cm}$. From Komatsu, Nenchūgyōji emaki, p. 17. Private collection.

The song describes a roaming shaman who performs divinations for fishermen in the hinterlands, who ridicule her whether her prophecies are right or wrong.

Returning to the scene in the Nenchügyoji emaki, at the corner of the crowd of people engaged in the cockfight, next to a small shrine, sits an old woman with her obi laid out under her (figure 3). With a drum used for divination placed in front of her, she has the typical appearance of a wandering shaman. It is thought that these shamans made a living by travelling to popular gathering spots and performing divinations, and would at times even give forms of public entertainment.

We will now situate the futanari described at the beginning of this essay within the spectrum of the male shamans and wandering shamans who both existed during the time of the Retired Emperor Goshirakawa. We can now connect the marginalization of male shamans or wandering shamans as peripheral figures, as seen in the imayō and the Nenchügyōji emaki, with the doubt and suspicion of society incurred by futanari whom, as described in the text of the "Futanari" section, "people found suspicious."

These historical and literary contexts unlock a greater understanding of the narrative in the "Futanari" scene. This is a rich, multifaceted narrative in which the concept of hermaphroditism, which was once consid- ered possible only in Buddhist texts, becomes associated with in-the-flesh male shamans. The male shaman who performed rituals to cure Emperor Sanjō's eye disease, the male shaman from the eastern hinterlands, the male shaman who danced beneath the gate to Sumiyoshi, the male shaman who donned a wig and woman's clothing, the wandering shaman from the bay of Tago, and the wandering shaman amid the crowd of peopleall of these figures are situated within text and image in a way that blurs the lines between truth and fiction.

When considered in light of the Buddhist sutra teachings on karmic retribution, the "Futanari" scene takes on an even greater complexity, revealing the true nature of the futanari to be fundamentally liminal. Returning to the text and image of the "Futanari" section, the text states that the figure whom people found suspicious "carried a drum around his neck as a soothsayer" and "had the appearance of a man, but would occasionally dress as a woman." The otherness of hermaphroditism is hence revealed. Moreover, the intersex figure is ridiculed and rejected by society, as indicated by the two intruders who laugh and point at him. By putting the intersex body of the male shaman on display and showing the spectator's reactions, the viewers of the scroll are themselves made to grasp the place of futanari within the social hierarchy. 
However, the otherness signified by hermaphroditism does not merely exclude or marginalize. It also possesses an appeal that draws out the interest of people. While the male shaman who appears in the imayo takes on a different appearance, he is still someone who holds an unusual sway over those around him, mesmerizing them with his incantations and performances. This is the unique charm of the male shaman who dressed in women's clothing.

Moreover, we cannot overlook the greater complexity of the physical body of the intersex figure in this depiction. Having both male and female sex organs, the futanari is ultimately neither a man in women's clothes nor a woman in men's clothes. The male guise (represented by the hunting robe, the black ebosh $i$ hat, and the moustache) and the female guise (represented by the deep red lips, cheeks, and crimson fan) exist simultaneously as one body, thereby transcending the male-female dichotomy. Realizing this, viewers of the scroll discover that the object of ridicule and pointed fingers is actually a part of themselves. In viewing the "Futanari" scene the viewer's sexuality itself becomes destabilized, prompting the question, "What is a male, what is a female, and what are you?"

\section{Conclusion}

The tale of an intersex figure transcending gender relates to yet another tale of bodily change that permeates the literature and art of the Insei period, namely the metamorphosing male, or the tale of the Dragon King's daughter found in the "Devadatta" chapter of the Lotus Sutra. According to the text, "The bodies of women are defiled and therefore cannot receive the teachings of the Buddha. They cannot achieve enlightenment."26 Women are thus scorned and cannot achieve buddhahood due to the Five Hindrances of their bodies: their inability to become the Bonten King, the Taishaku King, the Devil King, the Wheel-Turning King, and finally a buddha. However, Shakara, the daughter of the Dragon King (Sk. Sāgara-nāgarāja), hears a recitation of the Lotus Sutra at the age of eight and prays with earnest conviction that she achieve buddhahood. She offers a precious jewel in her possession to the Buddha. The Buddha accepts this offering, and in an instant, be-

26 Myōhō rengekyō, p. 35c. fore the whole world, the woman is transformed into a man and achieves buddhahood.

The woman with a body tainted by sin became a man, then a bodhisattva, and finally a buddha. The tale of the Dragon King's daughter, which vividly depicts the metamorphosis of the physical body, mirrors the tale of the intersex figure. According to the Buddhist teachings, being born anything other than a man is a mark of sin from a previous life. ${ }^{27}$ On the other hand, someone can be transformed into a man due to good deeds. Both of these conceptualizations transgress the boundaries of gender and as such, the assignment of binary gender identity. The intersex figure depicted in "Futanari" goes back and forth between two genders; it both accepts the scorn of the world and transcends it. The figure invalidates the question of whether the individual depicted is a man or woman and clears the way for a new tale to be told.

\section{Reference List}

Abe, Ryūichi. "Revisiting the Dragon Princess: Her Role in Medieval Engi Stories and Their Implications in Reading the Lotus Sutra." JJRS 42:1 (2015), pp. 27-70.

Abe Yasurō 阿部泰郎. “Sei no ekkyō: Chūsei no shūkyō, geinō, monogatari ni okeru ekkyō suru sei” 性の越境: 中 世の宗教/芸能/物語における越境する性. In Onna no ryōiki, otoko no ryōiki: Ikutsumono Nihon VI 女の領 域·男の領域: いくつもの日本 VI, ed. Akasaka Norio 赤坂憲雄 et al., pp. 197-223. Iwanami Shoten, 2003.

Abe Yasurō. "Sei no rinkai o ikiru: 'Chūsei Nihon no shūkyō to geinō no kyōkai ryōiki kara”” 性の臨界を生きる: 【中世日本の宗教と芸能の境界領域から】.Kan: Rekishi, kankyō, bunmei 環: 歴史·環境·文明 12 (2003), pp. 252-57.

Blacker, Carmen. The Catalpa Bow: A Study of Shamanistic Practices in Japan. London: Allen \& Unwin, 1975.

Bussetsu daijō zōzō kudokukyō 仏説大乗造像功德経 (Ch. Foshuo dacheng zaoxiang gongde jing). T 694, 16:793C. Hori Ichirō 堀一郎. Nihon no shāmanizumu 日本のシャー マニズム. Kōdansha, 1971.

27 Although this concept was widespread in Heian- and Kamakuraperiod society, it is also true that women did not themselves consider their bodies innately sinful. There has been a great deal of recent scholarship on this point; in particular, see Abe, "Revisiting the Dragon Princess." 
Kasuya Makoto 加須屋誠 and Yamamoto Satomi 山本聡 美, eds. Yamai no sōshi 病草紙. Chūō Kōron Bijutsu Shuppan, 2017.

Kim, Yung-Hee. Songs to Make the Dust Dance: The Ryōjin Hisho of Twelfth-Century Japan. University of California Press, 1994.

Kobayashi Taichirō 小林太市郎. “Butsumyō to Shamon jigoku zōshi” 仏名と沙門地獄草紙. In vol. 5 of Kobayashi Taichirō chosakushū 小林太市郎著作集, pp. 275-350. Tankōsha, 1974.

Kobayashi Taichirō. “Hekija emaki ni tsuite” 辟邪絵巻に 就て. In vol. 5 of Kobayashi Taichirō chosakushū, pp. 197-274. Tankōsha, 1974.

Komatsu Shigemi 小松茂美, ed. Nenchūgyōji emaki 年中行 事絵巻. Chūōkōronsha, 1977.

Minamoto no Shitagō 源順. Wamyō ruijushō: Shohon shūsei Wamyō ruijushō honbunhen 和名類聚抄: 諸本集成倭名 類聚抄本文編. Kyōto Daigaku Bungakubu Kokugogaku Kokubungaku Kenkyūjo 京都大学文学部国語学国文学 研究所, ed. Kyoto: Rinsen Shoten, 1968.

Mitsuhashi Junko 三橋順子. Joshō to Nihonjin 女装と日本 人. Kōdansha, 2008.

Myōhō rengekyō 妙法蓮華経 (Ch. Miaofa lianhua jing). T 262 9:35c.

Nakayama Tarō 中山太郎. Nihon fujo shi 日本巫女史. Ōokayama shoten, 1930.

Ryōjin hishō, Kanginshū, Kyōgen kayō 梁塵秘抄 · 閑吟 集 · 狂言歌謡. Ed. Kobayashi Yoshinori 小林芳規 et al. SNKBT 30

Shinbo Tōru 真保亨. “Harake-bon Jigoku zōshi no gadai to shutten” 原家本地獄草紙の画題と出典. Tsukuba Daigaku geijutsu nenpō 筑波大学芸術年報 (1985), pp. 22-25.

Shōbō nenjokyō 正法念処経 (Ch. Zhengfa nianchu jing). T 721 17:3c, 104a-b, 392b.

Tanaka Ichimatsu 田中一松. Jigoku zōshi 地獄草紙. Nihon emakimono shūsei 日本絵巻物集成. Vol. 9. Yūzankaku, 1930.

Ueno Naoteru 上野直昭. “Emakimono ni tsuite: Gaki zōshi kōsatsu” 繪卷物に就いて: 餓鬼草紙考察. Shisō思想 28 (1924), pp. 13-50.

Umezawa Megumi 梅沢恵. “Ya o hagu Bishamonten zō to ‘hekija-e’ no shudai” 矢を知ぐ毘沙門天像と「辟邪 絵」の主題. In Chūsei kaiga no matorikkusu II 中世絵 画のマトリックス, ed. Sanō Midori 佐野みどり, pp. 383-403. Seikansha, 2014.

Yamakami Izumo 山上伊豆母. Miko no rekishi: Nihon shūkyō no botai. 巫女の歴史: 日本宗教の母胎.

Yūzankaku, 1975.
Yamamoto Satomi 山本聡美. “'Yamai no sōshi’ ni okeru setsuwa no ryōbun: Otokomiko to shite no Futanari” 「病草紙」における説話の領分: 男巫としての二 形. In Nihon bungaku no tenbōo hiraku 2: Kaiga, imēji no kairo 日本文学の展望を拓く 2 ：絵画・イメ一 ジの回路, ed. Komine Kazuaki 小峯和明 and Deguchi Hisanori 出口久徳, pp. 81-95. Kasama Shoin, 2017.

Yamanaka Yutaka 山中裕, ed. Midō kanpaku-ki zenchūshaku: Chōwa 4 nen 御堂関白記全註釈: 長和四 年, pp. 112-13. Shibunkaku Shuppan, 2003.

Yanagita Kunio 柳田國男. “Fujo kō” 巫女考. Kyōdo kenkyū 郷土研究 1 (1913-1914), pp. 1-12.

Yanagita Kunio. Imo no Chikara 妹の力. Sōgensha, 1940.

Yanagita Kunio. “Tamayorihiko no mondai”玉依彦の 問題. In Nantō ronsō 南島論叢, ed. Iha-sensei Kinen Ronbunshū Henshū Iin 伊波先生記念論文集編纂委員, pp. 1-22. Okinawa Nippōsha, Naha, 1937.

Yanagita Kunio. “Tamayorihime kō” 玉依姫考. Kyōdo kenkyū 4:12 (1917), pp. 1-29.

Yanagita Kunio. Teihon Yanagita Kunio shū 定本柳田國男 集. Vol. 9. Chikuma Shobō, 1969.

Yanagita Kunio. Yanagita Kunio zenshū 柳田國男全集. Vol. 11. Chikuma Shobō, 1998. 